\title{
MANAJEMEN RANTAI PASOKAN JAGUNG ASALAN PADA CV AMIN DI LAMPUNG TENGAH
}

\author{
Rahmad Budiono, Achmad Syaichu \\ Sekolah Tinggi Teknologi Pomosda \\ Tanjung Anom, Nganjuk, Indonesia \\ Email : syaichu07@gmail.com
}

\begin{abstract}
Abstrak
Salah satu komoditi palawija yang memiliki peranan yang penting di Indonesia adalah jagung, karena merupakan sumber protein dan kalori yang sangat dibutuhkan oleh ayam peternak. Pengiriman yang belum tepat waktu merupakan penyebab belum efisiennya kinerja rantai pasokan jagung. Oleh karena itu penelitian ini bertujuan untuk (1) mengidentifikasi dan mengkaji pengelolaan rantai pasokan jagung pada CV. AMIN, (2) menganalisis kinerja rantai pasokan jagung dalam hal efisiensi dan pelaksanaan kemitraan, dan (3) menganalisis alternatif kebijakan pengembangan manajemen rantai pasokan berdasarkan hasil evaluasi rantai pasokan.Penelitian akan dilakukan di CV. AMIN, Jl. Raya Merapi, Lampung Tengah dan petani mitra yang berada di kabupaten Nganjuk. Penelitian mengenai manajemen rantai pasokan Jagung tersebut dilakukan pada bulan Desember 2012 hingga Januari 2013. Pengumpulan data dilakukan dengan observasi. Responden dalam penelitian ini adalah petani jagung yang berada di Nganjuk, Pengepul, pihak CV. AMIN, dan Gudang Ternak. Penelitian dilakukan dengan metode analisis deskriptif kerangka Food Supply Chain Networking (FSCN), analisis tataniaga, dan analisis deskriptif dengan menggunakan kesesuaian atribut.
\end{abstract}

Kata kunci : Manajemen Rantai Pasokan, Jagung Asalan.

\section{PENDAHULUAN}

Sektor pertanian merupakan salah satu sektor yang memberikan kontribusi yang penting untuk kemajuan perekonomian di Indonesia. Hal tersebut dapat dilihat dari 108,21 juta penduduk Indonesia yang bekerja, terdapat $38 \%$ penduduk Indonesia bekerja pada sektor pertanian. Selain itu, kontribusi sektor pertanian terhadap pendapatan nasional Indonesia dapat dilihat berdasarkan besarnya peningkatan nilai Produk Domestik Bruto (PDB). Pada tahun 2011 hasil sektor pertanian atas dasar harga berlaku yaitu sebesar Rp 716.065,3 Milyar meningkat menjadi Rp 858.252,0 Milyar, pada tahun 2012 mengalami pertumbuhan sebesar 19,9 persen, BPS (2012).

Produksi jagung nasional dari tahun ketahun meningkat secara signifikan berturutturut dari 9.654.000 ton (2010), 10.866.000 ton (2011), dan 11.225,000 ton (2012) dengan luas lahan 3.577.493 ha dengan produktivitas 34,53 kw/ha (Anonymous, 2006). Peningkatan ini disebabkan semakin banyaknya daerah-daerah yang mengembangkan, sedangkan produksi jagung Kabupaten Nganjuk pada tahun 2010, Produksi 18.328 ton, luas panen 4.132 Ha, Produktivitas 44,36 Kw/Ha. Pada tahun 2011, Produksi 17.643 Ton, Luas panen 3,865 Ha, Produktivitas 45,65 Kw/Ha. Dan pada tahun 2012 Produksi 19.377 Ton, Luas panen 3.960 Ha, Produktivitas 49,83 Kw/Ha.

Pada tahun 2012 ini, Kabupaten Nganjuk telah panen jagung baik di lahan sawah maupun hutan. "Tahun ini kami panen jagung sampai 29.000 hektare. Lahan di tempat kami ada yang dari sawah sampai 38 ribu hektare dan jagung ini sangat menjanjikan. (BPS, Nganjuk 2012).

Manajemen rantai pasokan sebagai proses bisnis dari pengguna akhir melalui pemasok yang memberikan produk, jasa, informasi, dan bahkan peningkatan nilai untuk konsumen dan karyawan. Melalui rantai pasokan, perusahaan dapat membangun kerjasama melalui penciptaan jaringan kerja (network) yang terkoordinasi dalam penyediaan barang maupun jasa bagi konsumen secara efisien. Salah satu hal terpenting dalam manejemen rantai pasokan adalah saling berbagi informasi, oleh karena itu dalam aliran material, arus kas, dan aliran informasi merupakan keseluruhan elemen dalam rantai pasokan yang perlu 
diintegrasikan, (Anatan L, 2000).

Lampung, khususnya daerah Lampung Tengah merupakan salah satu Kabupaten yang memiliki potensi permintaan yang sangat meningkat untuk produk jagung yang salah satunya yaitu jagung (DinasPertanian Lampung, 2010). Oleh karena itu, pengembangan terhadap usaha jagung perlu dikembangkan. Namun pengembangan usaha di Kabupaten Nganjuk, kususnya petani jagung masih terkendala dalam masa tanam atau masa jagung yang sifat tanamnya musiman dan dalam jaminan kesinambungan kualitas produk, minimnya jumlah pasokan, dan ketepatan waktu pengiriman. Penyebab lainnya adalah belum efisiennya kinerja rantai pasokan. Sehingga, Manajemen Rantai Pasokan memegang peranan penting dalam peningkatan bisnis jagung dan perlu dilakukan dengan baik, (Nuri, 2012).

Jagung Asalan secara umum mempunyai karakteristik antara lain: (1) produk mudah rusak jika setelah panen dan penggilingan tidak langsung dikeringkan, (2) budidaya dan pemanenan sangat tergantung iklim dan musim, (3) kualitas bervariasi. Ketiga faktor ini perlu dipertimbangkan dalam menganalisis Manajemen Rantai Pasokan Jagung Asalan, dan sebagai konsekuensi sistem pengukuran kinerja sangat diperlukan. Manajemen Rantai Pasokan merupakan proses penciptaan nilai tambah barang dan jasa yang berfokus pada efisiensi dari persediaan, aliran kas dan aliran informasi.

\section{A. Rumusan Masalah}

Perumusan masalah dalam penelitian ini adalah :

1. Bagaimana kondisi Manajemen Rantai Pasokan jagung asalan pada CV AMIN?

2. Bagaimana kinerja dari pelaksanaan Manajemen Rantai Pasokan jagung asalan pada CV AMIN?

3. Kebijakan apa yang dapat diterapkan sebagai alternatif dalam pengembangan Manajemen Rantai Pasokan jagung asalan pada CV AMIN?

\section{B. Tujuan Penelitian}

Adapun tujuan dari penulisan laporan Penelitian ini adalah :

1. Untuk mengetahui kondisi dan pengelolaan rantai pasokanjagung asalan pada CV AMIN.

2. Untuk mengetahui dan menganalisis kinerja rantai pasokan jagung asalan dalam hal efisiensi dan pelaksanaan kemitraan dalam rantai pasokan CV AMIN.

3. Untuk mendapatkan kebijakan sebagai alternatif dalam pengembangan Manajemen Rantai Pasokan CV AMIN.

\section{TINJAUAN PUSTAKA}

\section{A. Manajemen Rantai Pasokan}

Anatan L (2000), mendefinisikan manajemen rantai pasokan sebagai integrasi proses bisnis dari pengguna akhir melalui pemasok yang memberikan produk, jasa, informasi, dan bahkan peningkatan nilai untuk konsumen dan karyawan. Melalui rantai pasokan, perusahaan dapat membangun kerjasama melalui penciptaan jaringan kerja (network) yang terkoordinasi dalam penyediaan barang maupun jasa bagi konsumen secara efisien. Salah satu hal terpenting dalam manejemen rantai pasokan adalah saling berbagi informasi, oleh karena itu dalam aliran material, arus kas, dan aliran informasi merupakan keseluruhan elemen dalam rantai pasokan yang perlu diintegrasikan.

Menurut Jebarus (2001),Manajemen Rantai Pasokan merupakan pengembangan lebih lanjut dari konsep tataniaga untuk memenuhi permintaan konsumen. Konsep ini menekankan pada pola terpadu yang menyangkut proses aliran produk dari supplier, manufacture, retailer hingga kepada konsumen. Interaksi yang terjadi dalam Manajemen Rantai Pasokan memiliki arus bolak-balik antara anggota rantai pasokan, mulai dari petani hingga konsumen akhir.Sedangkan interaksi yang terjadi pada konsep tataniaga arus searah antar anggota rantai pasokan. 
Perubahan yang sangat cepat yang terjadi di dunia bisnis menyebabkan kompetisi diantara pemain-pemain bisnis menjadi semakin nyata. Peningkatan tingkat kompetisi tersebut ditandai dengan permintaan yang berfluktuasi, penurunan tingkat loyalitas konsumen (ternak), dan semakin singkatnya siklus hidup produk. Salah satu strategi yang dikembangkan dalam menghadapi permasalahan ketidakpastian tersebut adalah melalui strategi yang dikenal dengan Manajemen Rantai Pasokan.Di dalam strategi Manajemen Rantai Pasokan, setiap perusahaan merupakan pemasok sekaligus konsumen dari suatu sistem rantai pasokan tertentu.Aplikasi Manajemen Rantai Pasokan tersebut dapat memberikan dampak yang cukup berarti dalam peningkatan keunggulan kompetitif terhadap produk maupun pada sistem yang dibangun itu sendiri, Indrajit dan Djokopranoto dalam. (Qolbi Isnanto, 2009).

Manajemen Rantai Pasokan adalah pendekatan pengelolaan kegiatan-kegiatan dalam rangka memperoleh bahan mentah (proses budidaya) mentransformasikan bahan mentah tersebut (penanganan panen dan pascapanen) dan mengirimkan produk tersebut ke konsumen oleh pencari, pengumpul, dan pengecer melalui sistem distribusi. Konsep Manajemen Rantai Pasokan ini memiliki ruang lingkup yang sangat luas dimana pengelolaan rantai pasokan ini meliputi bagaimana mengelola proses mendapatkan bahan mentah, pengalokasian faktor produksi dari supplier, pengelolaan proses produksi itu sendiri, penggunaan teknologi di dalam proses produksi, mekanisme pengangkutan barang dan bahan baku, pemasaran melalui agen-agen distributor, pengelolaan modal, hutang dan piutang perusahaan, pengelolaan persediaan dalam gudang pemasaran melalui periklanan melalui media hingga barang tersebut dapat langsung dikonsumsi oleh konsumen akhir. (Darmaputra, 2005).

Gunasekaran et al (2004) Rantai pasokan merupakan hal yang dinamis dan melibatkan aliran informasi yang konstan, produk, dan keuangan antar tingkat-tingkat yang berbeda.Rantai pasokan menimbulkan gambaran atas pergerakan produk atau pasokan dari supplier kepada pembuat produk, distributor, pengecer, pelanggan sepanjang rantai.

\section{METODE PENELITIAN}

\section{A. Jenis dan Metode Pengumpulan Data}

Pengumpulan data dilakukan dengan observasi atau pengamatan langsung dan wawancara dengan pihak-pihak yang terkait.Jenis data terbagi menjadi dua yaitu data primer dan data sekunder.Data primer didapat dari observasi langsung.Data sekunder

diperoleh dari pihak yang terkait dan studi pustaka. Responden dalam penelitian ini adalah petani jagung asalan yang berada di Nganjuk, pengepul, pihak CV AMIN, dan gudang.

\section{B. Metode Pengolahan dan Analisis Data}

Kajian manajemen rantai pasokan membutuhkan suatu pendekatan metode analisis yang mampu menjabarkan permasalahan secara komprehensif. Penjabaran permasalahan rantai pasokan meliputi beberapa hal antara lain mengenai rantai pasokan, kinerja rantai pasokan, hambatan yang dihadapi rantai pasokan serta alternatif kebijakan bagi pengembangan rantai pasokan.

Oleh karena itu, dalam penelitian mengenai manajemen rantai pasokan jagung asalan pada CV AMIN ini akan dilakukan kajian yang meliputi deskripsi model rantai pasokan jagung asalan yang terjadi saat ini. Analisis kinerja rantai pasokan dalam hal kemitraan, serta alternatif kebijakan pengembangan rantai pasokan yang dapat dilakukan.

\section{Efisiensi Rantai Pasokan}

Beberapa tujuan yang ingin dicapai dari suatu pengelolaan rantai pasokan secara terintegrasi antara lain agar mampu menjamin produk diterima konsumen dengan harga yang bersaing, cepat, berkualitas, dan mudah diakses. Salah satu hal yang dapat dijadikan indikator bagi keberhasilan adalah efisiensi biaya disepanjang rantai pasokan, sehingga harga produk di tingkat konsumen menjadi kompetitif.Oleh karena itu, proses penyaluran 
produk jagung asalan dari petani hingga konsumen akhir harus mampu dilakukan dengan biaya yang efisien.

Menurut Said et al(2006), konsep tataniaga pertanian yang digunakan untuk menilai kondisi efisiensi dalam rantai pasokan jagung asalan meliputi perhitungan margin pemasaran jagung asalan serta farmer's share. Marjin tataniaga jagung asalan digunakan untuk melihat perbedaan harga di berbagai tingkat anggota rantai pasokan yang terlibat.Perhitungan margin diperoleh dari pengurangan biaya penjualan dengan pembelian pada setiap tingkat anggota rantai pasokan jagung asalan. Secara matematis hubungan antara marjin tataniaga yang diperoleh pelaku rantai pasokan dapat dituliskan sebagai berikut :

$$
\mathrm{Mi}=\mathrm{Hji}-\mathrm{Hbi}
$$

Keterangan :

$\mathrm{Mi}=$ Marjin tataniaga pada pasar tingkat ke-i $(\mathrm{Rp} / \mathrm{kg})$

$\mathrm{Hji}=$ Harga penjualan jagung asalan pada pasar tingkat $\mathrm{ke}-\mathrm{i}(\mathrm{Rp} / \mathrm{kg})$

Hbi = Harga pembelian jagung asalan pada pasar tingkat ke-i $(\mathrm{Rp} / \mathrm{kg})$

$\mathrm{i} \quad=1,2,3, \ldots . . \mathrm{n}$

Bagian yang diterima petani dari harga yang dibayar oleh konsumen akhir farmer's share juga menjadi hal yang dianalisis guna mengetahui kinerja efisiensi rantai pasokan jagng asalan.Konsumen akhir jagung asalan yang dibahas adalah pembeli yang membeli jagung asalan di gudang pakan ternak, sedangkan harga ditingkat konsumen akhir diasumsikan merupakan harga yang ditetapkan oleh gudang pakan ternak. Said et al (2006), analisis farmer's share merupakan analisis yang menggunakan penyebaran marjin tataniaga yang dapat dilihat berdasarkan bagian yang diperoleh masing-masing pelaku rantai pasok dengan keterlibatan dalam proses transpormasi output. Farmer's share memiliki hubungan negatif dengan marjin tataniaga, dimana semakin tinggi nilai marjin tataniaga jagung asalan maka nilai farmer's share akan semakin rendah. Secara matematis farmer's share dapat dinyatakan dalam persamaan sebagai berikut :

$$
\mathrm{FS}=\frac{\mathrm{FP}}{\mathrm{CP}} \quad \mathrm{x} 100 \%
$$

Keterangan :

$\mathrm{FS}=$ Farmer's share $(\%)$

$\mathrm{FP}=$ Harga di tingkat petani $(\mathrm{Rp} / \mathrm{kg})$

$\mathrm{CP}=$ Harga di tingkat konsumen akhir $(\mathrm{Rp} / \mathrm{kg})$ 


\section{Alur Penelitian}

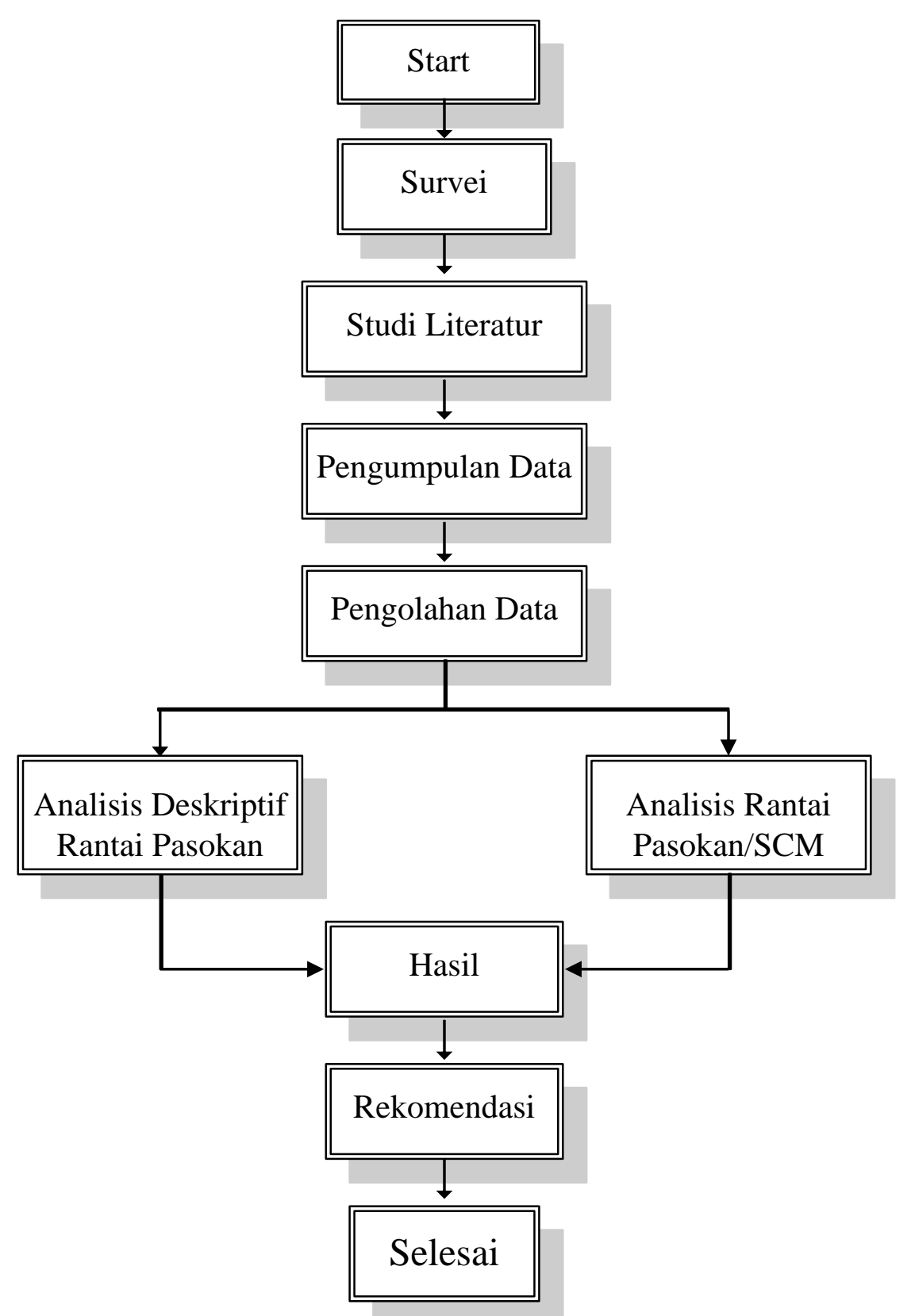

Gambar 1: Alur Penelitian 


\section{HASIL DAN PEMBAHASAN}

\section{A. Pemilihan Mitra}

Pemilihan mitra dalam rantai pasokan jagung asalan bertujuan untuk terciptanya jalinan kerjasama yang saling menguntungkan. Pemilihan mitra dalam rantai pasokan berkaitan erat dengan kriteria pemilihan dan proses pengambilan keputusan berdasarkan informasi. Tabel dibawah ini menjelaskan ktriteria-kriteria yang dipertimbangkan dalam pemilihan mitra.

Tabel 1 Kriteria Pemilihan Mitra

\begin{tabular}{|c|c|}
\hline Petani & Perusahaan \\
\hline $\begin{array}{l}\text { 1. Memproduksi produk yang sesuai } \\
\text { dengan kualitas yang diinginkan. } \\
\text { 2. Mampu mengirim produk tepat waktu } \\
\text { 3. Sanggup mensuplai secara continue } \\
\text { 4. Sanggup bertanggung jawab dan } \\
\text { mematuhi kesepakatan sebelumnya }\end{array}$ & $\begin{array}{l}\text { 1. Memproduksi produk yang } \\
\text { berkualitas } \\
\text { 2. Mampu mengirim produk tepat } \\
\text { waktu } \\
\text { 3. Sanggup mensupplai secara } \\
\text { continue } \\
\text { 4. Sanggup menerima penolakan } \\
\text { produk akibat adanya kerusakan }\end{array}$ \\
\hline Agen atau Pengepul & Ritel \\
\hline $\begin{array}{l}\text { 1. Memiliki reputasi yang baik. } \\
\text { 2. Memiliki data keuangan yang baik } \\
\text { 3. Memiliki penjualan yang baik. } \\
\text { 4. Memiliki fasilitas yang memadai } \\
\text { 5. Memiliki metode pemasaran yang } \\
\text { baik. }\end{array}$ & $\begin{array}{l}\text { 1. Memiliki reputasi yang baik. } \\
\text { 2. Memiliki performa penjualan yang } \\
\text { baik } \\
\text { 3. Memiliki fasilitas penjualan yang } \\
\text { baik } \\
\text { 4. Terletak dilokasi yang strategis }\end{array}$ \\
\hline
\end{tabular}

Sumber : CV AMIN, (2012)

\section{B. Kesepakatan Kontraktual}

Kesepakatan yang terjalin antara petani, pengepul atau agen dan CV AMIN memang masih berdasarkan pada sistem kepercayaan, namun terdapat beberapa ketentuan yang menjadi pegangan bagi kedua belah pihak.Dalam penentuan harga, ditentukan dengan melihat harga pasaran untuk produk jagung asalan yang telah menjadi harga pasaran di setiap musim panen jagung tiba.Perhitungan dilakukan berdasarkan pesanan dan jumlah bobot yang di pesan sebelumnya.Sedangkan kesepakatan yang terjalin antara CV AMIN dengan pihak gudang pakan ternak dilakukan dengan kontrak tertulis. Ketentuan dalam kontrak yang terjadi antara CV AMIN dengan pihak gudang pakan ternak diantaranya mengenai detail produk yang dipesan, penetapan harga dan jadwal pengiriman jagung asalan. Produk yang dipesan gudang pakan ternak yakni jagung asalan yang mempunyai kadar air berkisar dari $13 \%$ - $15 \%$.Dalam penetapan harga jagung asalan, sebelumnya CV AMIN melakukan tawar menawar dengan pihak Gudang pakan ternak. Jadi harga jagung asalan disetiap gudang pakan ternak berbeda-beda, tergantung pada kekuatan tawar menawar antara pihak CV AMIN dengan pihak gudang pakan ternak. Sedangkan untuk ketentuan pengiriman jagung asalan, CV AMIN mengirimkan jagung asalan setiap hari di waktu musim panen jagung tiba saja, dan jika tidak musim jagung CV AMIN, melakukan pengumpulan dahulu untuk memenuhi kapasitas muat truck dahulu baru melakukan pengiriman lagi. 
Tabel 2 Penilaian terhadap Petani, Pengumpul, Supplier dan Retiler dalam Rantai Pasokan

\begin{tabular}{|l|l|l|l|l|l|l|c|}
\hline \multicolumn{1}{|c|}{ Petani } & Nilai & \multicolumn{1}{|c|}{ Pengepul } & $\begin{array}{c}\text { Nila } \\
\text { i }\end{array}$ & Supplier & Nilai & Retiler & $\begin{array}{c}\text { Nila } \\
\text { i }\end{array}$ \\
\hline $\begin{array}{l}\text { Memproduksi } \\
\text { produk yang } \\
\text { berkualitas }\end{array}$ & S & $\begin{array}{l}\text { Memiliki sistem } \\
\text { pemesanan } \\
\text { yang efektif }\end{array}$ & S & $\begin{array}{l}\text { Memiliki } \\
\text { reputasi yang } \\
\text { baik }\end{array}$ & AS & $\begin{array}{l}\text { Memiliki } \\
\text { reputasi } \\
\text { yang baik }\end{array}$ & S \\
\hline $\begin{array}{l}\text { Harga dari } \\
\text { Produk }\end{array}$ & AS & $\begin{array}{l}\text { Ketersediaan } \\
\text { produk yang } \\
\text { continue }\end{array}$ & AS & $\begin{array}{l}\text { Memiliki } \\
\text { sistem } \\
\text { pemesanan } \\
\text { yang efektif }\end{array}$ & S & $\begin{array}{l}\text { Memiliki } \\
\text { record } \\
\text { penjualan } \\
\text { yang baik }\end{array}$ & S \\
\hline $\begin{array}{l}\text { Menerima dan } \\
\text { tanggung } \\
\text { jawab } \\
\text { terhadap } \\
\text { kesepakatan }\end{array}$ & AS & $\begin{array}{l}\text { Mau menerima } \\
\text { produk yang di- } \\
\text { reject (ditolak) }\end{array}$ & AS & $\begin{array}{l}\text { Memiliki } \\
\text { record } \\
\text { pemasaran } \\
\text { yang baik }\end{array}$ & S & $\begin{array}{l}\text { Memiliki } \\
\text { penjualan } \\
\text { yang baik }\end{array}$ & S \\
\hline $\begin{array}{l}\text { Mengirim } \\
\text { produk tepat } \\
\text { waktu }\end{array}$ & AS & $\begin{array}{l}\text { Mengirim } \\
\text { produk tepat } \\
\text { waktu }\end{array}$ & AS & $\begin{array}{l}\text { Memiliki } \\
\text { fasilitas } \\
\text { distribusi } \\
\text { yang memadai }\end{array}$ & TS & $\begin{array}{l}\text { Memiliki } \\
\text { fasilitas } \\
\text { yang } \\
\text { memadai }\end{array}$ & AS \\
\hline
\end{tabular}

Sumber : CV AMIN, (2012)

Keterangan : $S$ : Setuju

AS : Agak setuju

TS : Tidak setu

\section{Kinerja Kemitraan di Tingkat Petani Mitra Jagung Asalan}

Analisis tingkat kesesuaian atribut mengukur sejauh mana atribut dalam pelaksanaan kemitraan rantai pasokan telah memuaskan petani.Hal tersebut dapat dijadikan suatu indikator untuk menilai kinerja kemitraan di tingkat petani yakni jika petani merasa puas terhadap kemitraan yang dilakukan maka kinerja kemitraan rantai pasokan di tingkat petani jagung dinilai baik pula.Perbandingan dalam analisis kesesuaian atribut mencakup tingkat kepentingan dan tingkat kinerja.Tingkat kinerja merupakan persepsi petani terhadap hasil dalam pelaksanaan kemitraan dalam rantai pasokan yang diwakili dalam 10 atribut kemitraan.

Atribut kemitraan dalam keterbukaan informasi, akses permodalan, kualitas produk, tingkat penjualan, harga jual produk serta komitmen dan kerjasama merupakan atribut yang dianggap penting oleh petani jagung.Nilai dari tingkat kepentingan atribut kemitraan dalam keterbukaan informasi dan kualitas produk telah sesuai dengan kinerja yang dilakukan oleh petani.Petani menilai bahwa kinerja dalam dari keterbukaan informasi dan kualitas produk dalam rantai sudah cukup baik.Keterbukaan informasi merupakan salah satu indikator yang penting dalam pelaksanaan Manajemen Rantai Pasokan.

Meskipun rata-rata dari petani mitra menganggap bahwa akses permodalan merupakan atribut yang penting namun dalam pelaksanaannya, petani mitra merasa bahwa kinerja yang selama ini dilakukan belum baik.Hal tersebut dikarenakan terkadang terjadi keterlambatan pembayaran, sehingga menyebabkan berkurangnya pendapatan petani yang digunakan untuk usaha penanaman jagung.

Penilaian kinerja terhadap atribut tingkat penjualan dapat dirasa cukup baik, meskipun beberapa petani mengharapkan tingkat penjualan yang lebih dari kinerja yang ada.Rata-rata dari petani jagung yang menjadi mitra, merasa bahwa tingkat penjualan jagung asalan lebih tinggi dari jumlah dari tingkat penjualan sebelum bermitra. 
Tabel. 3 Penjualan Jagung Asalan Petani Sebelum Bermitra

\begin{tabular}{|l|c|c|}
\hline \multirow{2}{*}{ Petani } & \multicolumn{2}{|c|}{ Tahun } \\
\cline { 2 - 3 } & $\mathbf{2 0 0 9}$ & $\mathbf{2 0 1 0}$ \\
\hline Petani A & $2.609 \mathrm{~kg}$ & $2.014 \mathrm{~kg}$ \\
\hline Petani B & $2.422 \mathrm{~kg}$ & $2.835 \mathrm{~kg}$ \\
\hline Petani C & $2.890 \mathrm{~kg}$ & $3.455 \mathrm{~kg}$ \\
\hline Petani D & $2.710 \mathrm{~kg}$ & $2.854 \mathrm{~kg}$ \\
\hline
\end{tabular}

Sumber : Data sekunder

Tabel. 4 Penjualan Jagung Asalan Petani Sesudah Bermitra

\begin{tabular}{|l|c|c|}
\hline \multirow{2}{*}{ Petani } & \multicolumn{2}{|c|}{ Tahun } \\
\cline { 2 - 3 } & $\mathbf{2 0 1 1}$ & $\mathbf{2 0 1 2}$ \\
\hline Petani A & $3.115 \mathrm{~kg}$ & $3.765 \mathrm{~kg}$ \\
\hline Petani B & $2.970 \mathrm{~kg}$ & $4.835 \mathrm{~kg}$ \\
\hline Petani C & $2.895 \mathrm{~kg}$ & $3.655 \mathrm{~kg}$ \\
\hline Petani D & $3.655 \mathrm{~kg}$ & $4.854 \mathrm{~kg}$ \\
\hline
\end{tabular}

Sumber : Data sekunder

Harga jual produk merupakan atribut indikator dirasa penting bagi petani.Namun dalam kinerja pelaksanaannya, masih terdapat satu orang petani yang merasa belum puas terhadap harga jual yang telah disepakati.Petani merasa bahwa kinerja terhadap harga produk sudah cukup sesuai dengan harapan mereka.Rata-rata dari petani merasa puas dengan kesepakatan harga karena harga yang mereka peroleh merupakan harga tertinggi dari harga rata-rata jagung asalan di pasar. Sebelum mereka bermitra, mereka hanya menjual dengan harga $\mathrm{Rp} 2.200$ - Rp $2.250 / \mathrm{kg}$, namun Petani setelah bermitra para petani dapat menjual jagung asalan kepada pengepul sebesar Rp 2.350/kg. Dan kemudian akan di beli lagi oleh CV AMIN dengan harga Rp 2.700/Kg. Dari kenaikan harga jual petani sebelum dan sesudah bermitra, menimbulkan kepuasan dari petani mitra terhadap harga yang disepakati.

\section{Kinerja Kemitraan di Tingkat Pengepul atau Agen}

Penilaian mengenai kinerja kemitraan dalam rantai pasokan jagung asalan dilakukan kepada pihak pengepul.Pandangan dari pihak pengepul mengenai kinerja kemitraan yang terjalin dengan para pelaku rantai.

Komitmen dalam kerjasama, keterbukaan informasi, tingkat keuntungan, kualitas produk, tingkat penjualan serta harga jual produk merupakan beberapa atribut yang dinilai memiliki kinerja yang telah sesuai dengan harapan.Komitmen dan kerjasama yang dilakukan pengepul atas dasar kepercayaan.pengepul telah mengenal CV AMIN sebagai distributor dari produk-produk pertanian dengan kualitas baik.

\section{E. Efisiensi Rantai Pasokan}

Efisiensi rantai pasokan menjadi salah satu aspek yang perlu diperhatikan oleh pelaku rantai pasokan untuk menilai kinerja dari kegiatan Manajemen Rantai Pasokan.Efisiensi dalam saluran pemasaran (rantai pasokan) jagung asalan berfungsi untuk melihat apakah manfaat dan keuntungan dalam rantai pasokan telah tersebar secara merata dirasakan oleh seluruh anggota rantai.Selain itu, penilaian efisiensi juga dapat digunakan 
untuk melihat apakah sumberdaya rantai telah dialokasikan dengan baik ataukah masih memerlukan perbaikan dalam kerangka pelaksanaan fungsi masing-masing anggota rantai pasok.

Rantai pasokan yang dibahas dalam penelitian ini hanya memiliki satu saluran pemasaran yakni melibatkan petani, pengepul, CV AMIN dan gudang pakan ternak.Hal tersebut yang membedakan manajemen rantai pasokan dengan konsep tataniaga yang pemasarannya secara terbuka dan belum memiliki kontraktual.

\section{F. Marjin Tataniaga}

Salah satu indikator yang digunakan dalam menilai kinerja efisiensi suatu saluran (rantai) pemasaran adalah dengan menilai total marjin yang tercipta dalam upaya menyampaikan produk dari produsen hingga konsumen akhir. Jumlah marjin tataniaga terbentuk dari besarnya biaya yang dikeluarkan oleh setiap pelaku rantai serta profit yang diinginkan oleh setiap pelaku rantai tersebut. Tujuan dari manajemen rantai pasokan diantaranya adalah menyalurkan produk hingga konsumen akhir dengan harga yang kompetitif.Hal tersebut berarti bahwa suatu rantai pasokan dapat dikatakan efisien jika segenap anggota rantai dapat melakukan biaya dan marjin tataniaga secara rasional sehingga harga produk di tingkat konsumen menjadi kompetitif.Penilaian marjin tataniaga dalam rantai pasokan jagung asalan meliputi biaya yang dikeluarkan oleh petani, pengepul, CV AMIN, gudang pakan ternak.Harga yang menjadi acuan di tingkat konsumen akhir adalah harga yang ditetapkan oleh gudang pakan ternak.

Harga jual jagung asalan di tingkat petani sebesar Rp 2.350/kg.Harga yang ditetapkan sudah termasuk dengan biaya antar ke pengepul.Perhitungan marjin tataniaga untuk pengepul, dihitung dari pengurangan antara harga jual dengan harga beli.Hasil dari pengurangan tersebut dibagi dengan harga jual lalu dipersentasekan. Harga beli untuk jagung asalan pengepul kepada petani mitra sebesar $\mathrm{Rp} 2.350 / \mathrm{Kg}$ dan harga jual jagung asalan pengepul pada pihak CV AMIN sebesar Rp 2.700/Kg dan besar marjin tataniaga sebesar 12,96\%. Perhitungan marjin tataniaga untuk pengepul .

Harga beli jagung pengepul kepada petani mitra sebesar Rp. 2.350 dan harga jual jagung pengepul kepada pihak CV AMIN sebesar Rp. 2.700. Perhitungan marjin tataniaga pengepul dapat dilihat sebagai berikut:

Rp. 2.700 - Rp. $2.350=$ Rp. 350

$\operatorname{Rp} 350$

$\operatorname{Rp} 2.700$

$\mathrm{x} 100 \%=12,96 \%$

Marjin tataniaga untuk CV AMIN sebesar 18,51 persen, didapat dari pengurangan harga beli jagung aasalan di pengepul atau agen dengan harga jual dari CV AMIN kepada gudang pakan ternak. Hasil pengurangan tersebut kemudian dibagi dengan harga jual jagung yang ditetapkan CV AMIN untuk gudang, lalu dipersentasekan.Harga beli jagung asalan di CV AMIN adalah Rp 2.700/kg sedangkan harga jual yang ditetapkan oleh pihak CV AMIN sebesar Rp 2.350/kg.

Namun marjin tersebut tidak seimbang dengan perolehan marjin petani, pengepul serta gudang pakan ternak. Salah satu hal yang dapat dijadikan indikator bagi keberhasilan rantai pasokan jagung asalan adalah efisiensi biaya di sepanjang rantai pasokan, sehingga harga produk di tingkat konsumen menjadi kompetitif. Maka untuk menunjang keberhasilan dari rantai pasokan, sebaiknya CV AMIN mengefisiensikan biaya transaksi dan pemasaran.

Harga beli jagung di pengepul adalah Rp. 2.700/kg sedangkan harga jual yang ditetapkan oleh pihak CV AMIN sebesar Rp. 3.200/kg. Perhitungan marjin tataniaga untuk CV AMIN dapat dilihat sebagai berikut :

Rp. 3.200 - Rp. $2.700=$ Rp. 500

$$
\frac{\operatorname{Rp} 500}{\operatorname{Rp} 3.200} \quad x 100 \%=18,51 \%
$$


Margin tataniaga untuk gudang pakan ternak Lotte Mart sebesar 9,85 persen, didapat dari pengurangan harga beli jagung asalan di CV AMIN dengan harga jual dari gudangpakan ternak untuk konsumen. Hasil pengurangan tersebut kemudian dibagi dengan harga jual jagung yang ditetapkan gudang pakan ternak, lalu dipersentasekan.Harga beli jagung asalan di gudang pakan ternak (Lotte Mart) adalah Rp 3.200/kg sedangkan harga jual yang ditetapkan oleh pihak CV AMIN sebesar Rp 3.550/kg.

Harga beli jagung di gudang pakan ternak adalah Rp. 3.200/kg sedangkan harga jual yang ditetapkan oleh pihak gudang pakan ternak sebesar Rp. 3.550/kg. Perhitungan marjin tataniaga untuk gudang pakan ternak dapat dilihat sebagai berikut :

Rp. 3.550 - Rp. $3.200=$ Rp. 350

$\frac{\operatorname{Rp} 350}{\operatorname{Rp} 3.550} \quad x 100 \%=9,85 \%$

Margin yang diterima gudang pakan ternaklebih kecil dibandingkan dengan marjin dari CV AMIN.Gudang pakan ternak mengeluarkan biaya-biaya untuk pemasaran jagung asalan seperti ruang penyimpanan dan lain-lain. Perbandingan Margin Tataniaga Anggota Rantai Pasokan jagung asalan di CV AMIN dapat dilihat pada Tabel dibawah ini.

Tabel 5 Perbandingan Perolehan Margin Anggota Rantai Pasokan Jagung Asalan

\begin{tabular}{|l|c|}
\hline \multicolumn{1}{|c|}{ Pelaku Rantai } & Margin Tataniaga \\
\hline Pengepul/Agen & $12,96 \%$ \\
\hline CV AMIN & $18,51 \%$ \\
\hline Gudang Pakan Ternak & $9,85 \%$ \\
\hline
\end{tabular}

Sumber :Data olahan

\section{G. Farmer's Share}

Nilai farmer's share yang terbentuk dalam rantai pasokan jagung asalan sudah wajar bila dibandingkan dengan marjin yang diterima CV AMIN selaku anggota rantai pasok.Berikut merupakan perhitungan farmer's share yang diperoleh petani mitra.

$$
\mathrm{FS}=\frac{\mathrm{Rp} 2.350}{\mathrm{Rp} 3.550} \times 100 \%=66,19 \%
$$

Hasil analisis efisiensi tataniaga menunjukkan bahwa marjin tataniaga yang terbentuk dalam rantai pasokan jagung asalan dari studi kasus CV AMIN memiliki nilai yang relatif besar.Pembagian manfaat dan keuntungan dalam rantai pasokan pun belum merata, dimana CV AMIN menjadi pihak kedua setelah petani yang memiliki keuntungan yang besar dibandingkan pelaku rantai pasokan antara pengepul dan gudang pakan. Biaya pengeluaran yang dapat diminimalisir antara lain adalah biaya pengeringan jagung yang selama ini dilakukan dua kali oleh pengepul dan CV AMIN. Hal tersebut akan berdampak pada biaya keseluruhan dalam rantai pasokan yang pada akhirnya membuat harga jual di tingkat konsumen akhir lebih tinggi. Kegiatan pengeringan secara terpadu oleh satu pihak saja diharapkan dapat membuat biaya pengeluaran lebih efisien. 


\section{KESIMPULAN}

A.Kesimpulan

Berdasarkan hasil penelitian manajemen rantai pasokan jagung asalan yang dilakukan, maka dapat diperoleh beberapa kesimpulan sebagai berikut :

1. Kondisi manajemen rantai pasokan jagung asalan di CV AMIN, yang saat ini sedang berjalan belum sepenuhnya optimal disebabkan karena

a. Peran dari anggota pendukung, terutama dalam aliran modal untuk para petani mitra. Dalam hal pinjaman modal usaha, yang petani dapatkan hanya, berasal dari CV AMIN.

b. Aliran informasi yang belum berjalan dengan baik. CV AMIN sebagai pihak yang langsung berhubungan dengan pihak gudang, kurang memberikan informasi mengenai produk tolakan.

2. Kinerja dari pelaksanaan manajemen rantai pasokan jagung asalan di CV AMIN masih belum memiliki kinerja yang baik dalam hal efisiensi maupun kemitraan. Dilihat dari 10 atribut kemitraan yang ada masih kurang optimal, menurut pelaku rantai pasokan yang terdiri dari akses permodalan, efisiensi biaya transaksi dan pemasaran.

3. Alternatif kebijakan CV AMIN yang dapat diterapkan bagi pengembangan rantai pasokan jagung asalan antara lain dukungan pemerintah, trust building, dan kesepakatan kontraktual petani dengan pengepul maupun antara pengepul dengan CV AMIN.

\section{B. Saran}

Peran pemerintah nyata dibutuhkan dalam kegiatan rantai pasokan jagung asalan ini. Sangat disayangkan apabila potensi yang dimiliki petani ini tidak didukung oleh pemerintah, khususnya petani jagung, yang kerap merasakan kekurangan modal usaha dan belum sama sekali disentuh oleh bantuan modal dari luar kecuali CV AMIN. Peran aktif petani dalam mengusulkan kesepakatan kontraktual diperlukan agar kesepakatan ini dapat cepat terwujud.

Selain itu, pengepul atau agen sebaiknya memperbaiki alat perontok jagung glondongan agar jagung yang telah menjadi pipilan tidak banyak kecampuran kotoran pecahan dari daging jagung (janggel) sehingga jagung yang sudah dipipil tidak kotor, dan tidak menambah besar kadar air dari jagung sehingga tidak mengalami penurunan kualitas dan penolakan.

\section{DAFTAR PUSTAKA}

[1] Anatan, Lina dan Lena Ellitan. 2008. Supply Chain Management. Bandung :Alfabeta.

[2] Asril, Zikra. 2009. Analisis Kondisi dan Desain Indikator Kinerja Rantai pasokan Hasilbumi di Sentra Hortikultura Cianjur, Jawa Barat.[Skripsi]. Bogor. Fakultas Manajemen. Institut Pertanian Bogor.

[3] Chopra S dan P. Meindl. 2007. Supply Chain Management: Strategy, Planning and Opertiation. Pearson Prentice Hall, New York.

[4] Dinas Pertanian Kabupaten Nganjuk http://www.nganjukkab.go.id/ web/index.php/ Dinas-Daerah/dinaspertanian.html.(diakses14 maret 2013 rabu 20.29).

[5] http://jatim.bps.go.id/epub/2012/indikatorpertanian2012/files/search/searchtext.xml. (diakses Maret 2013 13.16).

[6] http://www.nganjukkab.go.id/web/index.php/jagung.html. (diakses jumat 22 Maret 2013 02.23).

[7] http://www.antaranews.com/berita/342958/indonesia-surplus-jagung.(diakses jumat 22 Maret 2013 00.23).

[8] http://hargajagungbns.blogspot.com/2012/12/standar-nasional-indonesia-si-mutu.html. (diakses 18 april 2013. 15.01).

[9] http://www.docstoc.com/docs/36608658/ABstrak-hasil-PenelitianPertanianKomoditas- Hasil-Bumi-(pdf). (12 maret 2013 selasa 20.12).

[10] http://berlaga92.wordpress.com/ (diakses 8 Mei 2013 di akses 06.47). 
[11] Indrajit, R. E dan Djokopranotao, R. E. 2002. Konsep Manajemen Supply Chain, Cara Baru Memandang Mata Rantai Penyediaan Barang.Jakarta : Grassindo.

[12] Pusat Penelitian dan Pengembangan Pertanian Departemen Pertanian Jagung.http:// perkebunan.litbang.deptan.go.id/index.php?option= com_content\&task=view\&id=16\&Itemid=3. (diakses 13 maret 2013 rabu 14.51).

[13] Said Al, Bayu AS, Clara LB, Hoetomo L, Riri Satria, Soerjo W, dan Zaldi IM. 2006.Produktivitas dan Efisiensi denganSupply Chain Management. Jakarta : Sekolah Tinggi PPM.

[14] Specman, $R$; Kamauff, $J$ \& Myhr, N. (1998) "An empirical investigation into Supply Chain Management: a perspective on partnerships", International Journal of Physical Distribution \& Logistics Management, Vol. 28, No. 8, pp. 630-650. 